\title{
Um banquete euclidiano
}

\author{
Júlio Vellozo ${ }^{1}$
}

GALVÃO, Walnice. Euclidiana, ensaios sobre Euclides da Cunha. São Paulo: Companhia das Letras, 2009. 327 p.

Euclidiana, ensaios sobre Euclides da Cunha, de Walnice Nogueira Galvão, é um livro que desperta duplo interesse. Por um lado, oferece um verdadeiro banquete sobre o autor de Os sertões, com ensaios instigantes sobre os mais variados aspectos de sua obra. Por outro, é um retrato em cores da trajetória intelectual da autora que, apesar de não resumir sua produção aos estudos euclidianos, já escreveu doze livros sobre o assunto.

A obra é uma espécie de antologia de escritos sobre Euclides da Cunha, numa seleção de quinze ensaios, publicados entre 1984 e 2009. Os textos estão organizados em quatro partes: a primeira delas trata de questões ligadas à análise literária da obra euclidiana; na segunda, temas biográficos se somam a diálogos com outros especialistas; a terceira, aborda a epistolografia; já a parte final versa sobre a edição da obra de Euclides da Cunha.

Alguns grandes temas perpassam os ensaios, por cima, inclusive, da divisão feita no livro e descrita anteriormente. Um deles é o que talvez possamos chamar de análise interna da obra. Em vários dos ensaios, a autora busca compreender a escrita euclidiana, e o faz sempre de modo muito revelador. A começar pela afirmação de que em Os sertões tudo é narrativa - inclusive a primeira parte do texto, bastante naturalista, denominada "A terra”. É muito bonita a demonstração feita por Walnice Galvão de que, mesmo quando descreve paisagens, Euclides recorre à construção de prosopopeias, dando vida aos seres inanimados, construindo um "Genesis não pronto, porém em devir".

Outra face da narrativa euclidiana desvendada pela autora é o constante jogo de contrastes, feito, por exemplo, por meio do permanente

1 Mestrando do Programa Culturas Brasileiras do Instituto de Estudos Brasileiros da Universidade de São Paulo. E-mail: juliovellozo@gmail.com 
uso dos oxímoros, como na expressão "hércules-quasímodo", emprestada de Victor Hugo. Mas não se trata apenas de um recurso de linguagem: “É o que podemos chamar de pensamento oxímorótico, pois o oxímoro em Euclides não só orna como expressa a dificuldade real de alcançar uma síntese entre doutrinas contraditórias" (p. 55; grifo nosso).

Esta dificuldade não era apenas de Euclides da Cunha, mas da intelectualidade de sua época, que sempre às voltas com teorias importadas, não conseguia produzir um pensamento mais coerente e que resultasse em sínteses. O esforço de compreender o Brasil, feito por meio da transposição de esquemas teóricos exógenos, era bastante obstado por esta limitação. Para a autora, esse problema, malgrado as diferenças, permanece até os dias de atuais.

Deriva daí a ideia de que a narrativa de Os sertões é construída em torno de uma polifonia exasperada. Euclides, como um regente, traz à tona uma série de afirmações, de opiniões, de invectivas, muitas vezes contraditórias entre si. Elas formariam uma espécie de "simpósio, cujos convivas estão ausentes, mas em que as ideias em entrechoque os substituem em presença viva nas páginas do livro" (p. 36). Euclides conduz tal polifonia não sem alma ou friamente, mas como um tribuno, discursando, tirando, da fricção entre visões conflitantes, a força da narrativa.

Outra característica muito interessante de Os sertões, trazida à tona pela autora, é a intertextualidade com a Bíblia. Feita de chofre a afirmação intriga: como um homem tão influenciado pelo cientificismo anticlerical poderia dialogar logo com os textos bíblicos? Mas uma cidade de Deus invertida está lá, demonstrada de forma inconteste no ensaio "Polifonia e paixão", talvez o mais rico da coletânea.

Ainda nessa chave está o estudo sobre as revisões que Euclides da Cunha realizou nas sucessivas edições que conheceu de Os sertões. Em diferentes ensaios, a autora demonstra que a coisa beirou a obsessão: só de vírgulas vagabundas, como as denominou o autor, foram retiradas mil, aproximadamente. Estudando o sentido de tais emendas, em um trabalho que só pode ser realizado com dedicação beneditina, Walnice Galvão percebeu que havia nelas uma tentativa de construção de uma prosódia mais brasileira. Soubessem disso, os modernistas, que tiveram mais tarde a mesma preocupação, não teriam desprezado Euclides, malgrado sua linguagem empolada e seu estilo grandiloquente.

Outra ideia que perpassa vários ensaios, marcadamente na primeira parte do livro, é a relação do autor de Os sertões com a paisagem e com as viagens. Euclides, ainda moço, já se encantava com a imagem e os significados dos sertões profundos, o que a autora demonstra por meio de poemas da adolescência e da primeira mocidade. Um deles é 
especialmente interessante, demonstrativo de um interesse do autor pelo bandeirantismo:

E ao ritmo de esplêndidas canções

Levantou-lhes os muros triunfantes

Heróica e sonhadora

A corte febril dos bandeirantes,

Nas marchas triunfais pelos sertões.

(p. 55)

A partir dessa ideia, a autora constrói uma relação entre Euclides, Joseph Conrad e Lawrence das Arábias, em uma passagem das mais fortes do livro. Conrad é evocado por suas narrativas sobre o mar, enquanto Lawrence comparece com seu encanto pelo deserto. Representam pontos de apoio para compreender Euclides e seu sertão.

Os três autores teriam em comum: "Primeiro, a demanda de arenas propícias ao heroísmo, às provações do corpo e da alma. Segundo, a percepção da sociedade desse espaço como melhor do que ao outra, da qual provêem. E, terceiro, a idealização do coletivo" (p. 72). Além disso, os três têm uma relação complexa com o colonialismo (lato sensu) que representam. A um só tempo são seus agentes e seus mais firmes denunciadores. Especialmente Conrad e Euclides construíram peças poderosas de denúncia, que marcariam a visão sobre os processos de modernização autoritária.

Há ensaios que apenas tangenciam Euclides, e que nem por isso são menos interessantes. É o caso do que trata da obra do escritor Victor Hugo. Depois de traçar uma biografia breve do autor francês, Walnice Galvão mapeia sua influência sobre autores brasileiros como Machado de Assis, Castro Alves e o próprio Euclides da Cunha.

Há ainda os ensaios que tratam de aspectos biográficos. O mais interessante é o que tenta desvendar o ensino que Euclides recebeu na Escola Militar. Apoiada em pesquisas do general Jeová Motta, especialista na história do ensino militar no Brasil, Walnice Galvão empreende um mergulho profundo na vida acadêmica de Euclides, trazendo à luz aspectos muito interessantes, como as habilidades técnicas adquiridas aí e que seriam usadas em Os sertões.

Ainda há outra série de ensaios que tratam dos encontros da autora com outros euclidianos. Walnice Galvão busca dividir o legado de principal estudiosa da obra com uma série de intelectuais, cujas ideias são expostas no livro, como José Calasans, erudito estudioso da saga da Canudos; Eduardo Galloti, organizador da Semana euclidiana de São 
José do Rio Preto; Antonio Houaiss, filólogo e estudioso da obra do autor; Franklin de Oliveira, jornalista e ensaísta maranhense que igualmente escreveu obra sobre Euclides da Cunha.

É uma pena que tenha comparecido pouco no livro a face amazônica da obra euclidiana. Tratada de soslaio em alguns ensaios, as ideias de Euclides da Cunha sobre o tema - que depois ficariam consolidadas na publicação póstuma $\dot{A}$ margem da história - não receberam a atenção merecida. Há no livro um pequeno ensaio que critica uma edição mal feita de $A$ A margem da história. Mas nele a autora não se aprofunda no conteúdo da obra, apenas alerta para os graves equívocos constantes na edição.

Outro problema é a ausência de uma introdução escrita especificamente para o livro - algo indispensável para explicar a lógica da coletânea e o contexto no qual cada ensaio foi produzido. Desempenha o papel de apresentação, um ensaio escrito em 2004, que, naturalmente, não foi escrito com tal finalidade.

Apesar desses pequenos óbices, Euclidiana, ensaios sobre Euclides da Cunha é uma leitura fundamental, além de muito agradável. A diversidade dos temas abordados, verdadeira antologia de uma vida de estudos, oferece um banquete de variados sabores, tanto para euclidianos mais versados quanto para quem pretende iniciar um aprofundamento na obra do autor. 